\title{
Gac (Momordica cochinchinensis Spreng.) fruit and its potentiality and superiority in - health benefits
}

\author{
Ali Abdulqader, ${ }^{a}$ Faisal Ali, ${ }^{a, b}$ Amin Ismail, a, ${ }^{*}$ and Norhaizan Mohd Esa,
}

\author{
aDepartment of Nutrition and Dietetics, Faculty of Medicine and Health Sciences, Universiti Putra Malaysia, Serdang, Selangor, Malaysia. \\ bBiochemistry \& Molecular Biology Department, University Hospital, Faculty of Medicine and Health Sciences, Sana'a University, Yemen. \\ cResearch Center of Excellent, Non-Communicable Diseases, Faculty of Medicine and Health Sciences, Universiti Putra Malaysia, Serdang, Selangor, Malaysia. \\ ¿Laboratory of Molecular Biomedicine, Institute of Bioscience, Universiti Putra Malaysia, Serdang, Selangor, Malaysia. \\ *Correspondence to Amin bin Ismail (email: aminis@upm.edu.my). \\ (Submitted: 09 October 2018 - Revised version received: 22 October 2018 - Accepted: 14 November 2018 - Published online: 26 December 2018)
}

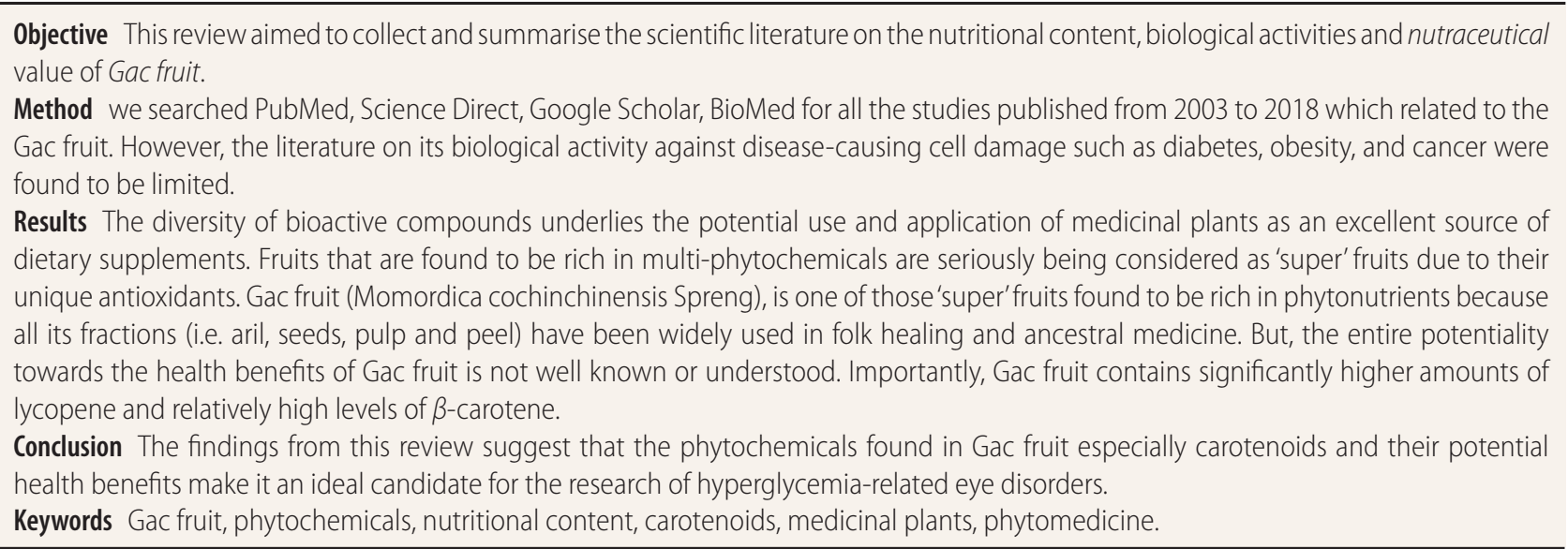

\section{Introduction}

The moist tropical weather in the Southeast Asian Region (SAR) is a rich source of nutrient for medicinal plants that has been used for generations for multiple purposes and applications. From among the abundance and wide variety of fruits and vegetables found across the region, particularly in Vietnam, Gac fruit is reputed to be an exceptional source of phytochemicals. "Gac" is the popular name given to this tropical fruit found in Vietnam as mentioned, as well as grown in other locations throughout the Southeast Asia Region. ${ }^{2}$ The Gac fruit is known by several other names such as (Fak Kao) in Thailand, (Teruah) in Malaysia, (Mak Kao) in Laos, (Bhat Kerala) in India, (Moc Niet Tu) in China, and the English name is 'Spiny bitter gourd' or 'Sweet gourd'.

Nutritionally, Gac fruit contains extraordinarily elevated or high-levels of carotenoids, particularly $\beta$-Carotene, lycopene, and lutein, $\alpha$-tocopherol, and essential fatty acids available in its portions (i.e. peel, pulp, aril, and seeds). ${ }^{4}$ This fruit also contains relatively high levels of polyphenols and flavonoids. ${ }^{5}$ The biological activities of these bioactive compounds have been established via their ability to scavenge free radicals and act as antioxidants. Recently, the food and pharmacological industry have taken a keen interest in $\mathrm{Gac}$ fruit and producing Gac fruit products such as Gac powder, Gac oil capsules, Gac juice, and frozen Gac fruit. Moreover, these products have been released into the market serving as food additives, in cosmetics, and for medicinal and pharmaceutical purposes. ${ }^{3}$ Figure 1 shows the morphology of Gac fruit.

\section{Methodology}

An Internet online literature search was carried out to collect and compile relevant research data for this review. The following terms were used in performing the searches; Momordica cochinchinensis Spreng, Gac fruit, carotenoids, age-related macular degeneration, diabetic retinopathy. All data related to Gac fruit and other keywords were downloaded via several Internet search engines: PubMed, ScienceDirect, Google Scholar, and BioMed.

\section{Carotenoids in Gac Fruit}

All parts or portions of the Gac fruit (i.e. the peel, pulp, and aril) were found to be an excellent source of carotenoids. Indeed, the aril of the Gac fruit was reported to comprise a high amount of lycopene, about 10 -fold higher than that known to be in lycopene-rich fruit and vegetables. ${ }^{6}$ In a separate study, Vuong et al. $^{7}$ reported the lycopene and $\beta$-Carotene concentrations of the edible portion of Gac fruit to be 802 and $175 \mu \mathrm{g} / \mathrm{g}$ respectively. Also, in the same year, Aoki et al. ${ }^{6}$ reported $380 \mu \mathrm{g} / \mathrm{g}$ of lycopene and $101 \mu \mathrm{g} / \mathrm{g}$ of $\beta$-Carotene in Gac aril. In a further study, Ishida et al. ${ }^{1}$ found very high levels of carotenoids ( $\beta$-Carotene, $\alpha$-carotene, and lycopene) in Gac aril, with concentrations of 718, 107, and $2227 \mu \mathrm{g} / \mathrm{g}$, respectively. Another study reported Gac aril content of lycopene and $\beta$-Carotene was 408 and $83 \mu \mathrm{g} / \mathrm{g}$ respectively. ${ }^{8}$ While Nhung et al. ${ }^{9}$ mentioned that Gac fruit had the highest amount of lycopene with a concentration of $3728 \mu \mathrm{g} / \mathrm{g} \mathrm{FW}$ and that the concentration of $\beta$-Carotene was 


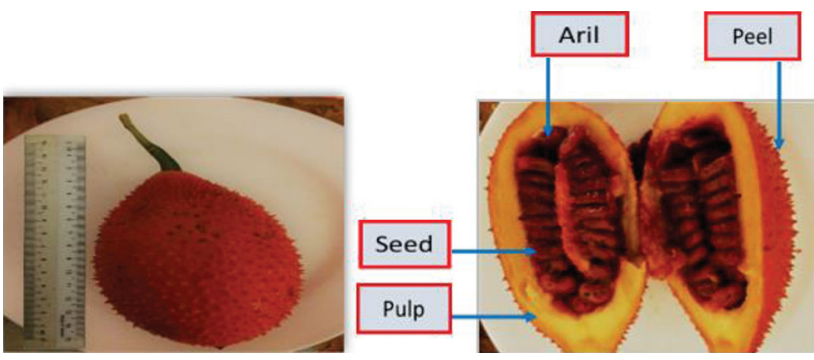

Fig. 1 Gac (M. cochinchinensis Spreng) fruit morphology.

similarly very high at $379 \mu \mathrm{g} / \mathrm{g}$ FW. Recent reports have indicated very promising and excitingly high-levels of both lycopene and $\beta$-Carotene in Gac aril, of 6800 and $2900 \mu \mathrm{g} / \mathrm{g}$ respectively. ${ }^{10} \mathrm{~A}$ further study reported concentrations of 6300 and $5700 \mu \mathrm{g} / \mathrm{g}$ for lycopene and $\beta$-Carotene respectively. ${ }^{11}$ Investigating the carotenoids in Gac fruit, carrot root and tomato fruit, as to which was more digestible, determined that both carotenoids (lycopene and $\beta$-Carotene) from Gac fruit were found to be at least eight times higher than the carotenoids found in carrot root and tomato fruit. ${ }^{12}$

Besides Gac aril, the yellow pulp and the peel of the Gac fruit were equally found to be a rich source of carotenoids. It was reported that the total carotenoid content of Gac pulp was $283 \mu \mathrm{g} / \mathrm{g}$, and this concentration is high compared with other carotenoid-rich fruits. ${ }^{8}$ The Gac pulp content of carotenoids was further analysed, revealing that Gac pulp contains $22 \mu \mathrm{g} / \mathrm{g}$ of $\beta$-Carotene and $0.9 \mu \mathrm{g} / \mathrm{g}$ of lycopene, and in addition to $\beta$-Carotene, the Gac pulp was also found to contain zeaxanthin and $\beta$-Cryptoxanthin. ${ }^{6}$ Furthermore, in addition to lycopene and $\beta$-Carotene, Gac peel was found to be remarkably, if not extremely rich in lutein, and much higher than found in the other fractions of the fruit, $(52,020 \mu \mathrm{g} / \mathrm{g}){ }^{5}$ However, at this stage, only the aril has been processed as the peel and pulp which constitute a significant quantity (15\% and $42 \%$ respectively) of the total weight of the fruit, are usually discarded. Previous in vitro digestion studies concluded that the bioavailability and bioaccessibility of carotenoids from Gac fruit aril were much higher than those from carrot and tomato. ${ }^{12}$

\section{Fatty Acids in Gac Fruit}

In addition to carotenoids, the fatty acid content found in Gac fruit has been investigated by several researchers. Fortunately, the existence of unsaturated fatty acids in Gac fruit was found to be relatively high. ${ }^{1}$ It was reported that $100 \mathrm{~g}$ of $\mathrm{Gac}$ seed pulp contains $852 \mathrm{mg}$ of fatty acids, and of that total amount, $70 \%$ was found to be unsaturated and 50\% was polyunsaturated. ${ }^{13}$ A further investigation reported that the Gac seed pulp content of fatty acids was $102 \mathrm{mg} / \mathrm{g}$ of the edible portion. ${ }^{7}$ Remarkably, oleic, palmitic, and linoleic acids were found to be predominant in Gac aril (32.3\%, 29.2\%, and 28.1\% respectively), while the predominant fatty acid found in Gac seed was stearic acid with small levels of linoleic, oleic and palmitic acids of $60.5 \%, 20.3 \%, 9 \%$, and $5.6 \%$ respectively. ${ }^{1}$ In a separate study by Newly, the total percentage of unsaturated fatty acids in Gac aril was reported to be $71.38 \%$, which was much higher than that of saturated fatty acids, with a final percentage of $28.62 \%$. Indeed, the most dominant fatty acids were oleic acid $48.99 \%$ followed by palmitic acid $24.18 \%$ and linoleic acid $21.09 \%{ }^{14}$

\section{Phenolic and Flavonoid Compounds in Gac Fruit}

Phenolic and flavonoid compounds were also found in Gac fruit. A study reported that the concentrations of phenolics and flavonoids found in Gac fruit were about 26.08 and 1.32 mg/100 g, respectively. ${ }^{15}$ Another study reported that the Gac fruit content of phenolics and flavonoids was investigated by several researchers, where it was determined that Gac peel, pulp, and aril content of phenolics was 55, 205, and $191 \mu \mathrm{g} / \mathrm{g}$ FW respectively, whereas Gac peel, pulp, and aril content of flavonoids was $0.118,0.143$, and $0.084 \mathrm{mg} / \mathrm{g}$ FW respectively. ${ }^{16}$ Gac fruit content of the phenolic and flavonoid compound variety among the fractions based on the maturity stages determined that ferulic acid and $p$-hydroxybenzoic acid were most apparent in Gac pulp, while apigenin, rutin, and luteolin were the main compounds found in mature pulp and aril.

\section{Traditional and Epidemiological Uses}

Gac fruit is indigenous to Vietnam and Southeast Asian countries and is used and consumed as a dietary supplement as well as for medicinal purposes. In Vietnam, Gac aril is cooked with rice to provide a scrumptious glossy look, with an oily taste for the slimy traditional rice dish named as ("xoi" gac), which is served during special occasions and festivals like Lunar New Year, birthdays, and weddings. ${ }^{3}$ Besides that, Gac oil after being extracted from the aril has also been used as a tonic and given to lactating or pregnant women and children to treat dry eyes (xerophthalmia) and night-blindness vision. ${ }^{2}$ It is also reported that the application of Gac oil is used to heal skin infections, wounds and burns, and has helped to stimulate cell growth and closure in wounds.

In China, the seed of the Gac fruit has been utilised for many generations. The Gac seed (in Mubiezi, China) has been traditionally used to treat inflammation, swelling, scrofula, tinea, diarrhoea with skin infections such as sores, carbuncles, furuncles and boils in humans and animals. ${ }^{17}$ In Bangladesh, the $M$. cochinchinensis Spreng known as 'Kakroal' or 'kark gach', uses all Kakroal fractions (i.e. fruit, seed, leaf, and roots) in medicinal systems for the treatment of various ailments such as cancer, diabetes, liver diseases, skin infections, itches, rheumatoid arthritis, colic, and blood purification. ${ }^{18}$ Thirty days of Gac fruit nourishment was found to improve $\beta$-Carotene levels among 185 preschoolers who were selected based on their high risk of Vitamin A deficiency.?

\section{Antioxidant Activities of Gac Fruit}

The antioxidant activity of Gac fruit has been examined using diphenyl-picrylhydrazyl (DPPH) radical scavenging, ferric reducing antioxidant power (FRAP), and 2,2'-azino-bis(3-ethy lbenzothiazoline-6-sulphonic acid (ABTS). These assays are widely used and accepted in evaluating the antioxidant properties of different compounds in foods, plants, fruits, and herbs. Moreover, different fractions of the Gac fruit at different maturity stages have been assessed regarding their potential antioxidant FRAP, by applying DPPH assays. The results showed that Gac aril at the fully ripened stage had the highest FRAP value at $531.17 \mu \mathrm{mol} / \mathrm{g}$. In the same study, the DPPH assay test 
showed that Gac peel and pulp had the highest antioxidant activity at the immature stages of 2.56 and $2.35 \mu \mathrm{mol} / \mathrm{g}$, respectively. ${ }^{5} \mathrm{~A}$ separate study reported that $\mathrm{DPPH}$ and FRAP assessments of $100 \mathrm{~g}$ of Gac fruit extract, were equivalent to 45.1 and $5.8 \mathrm{mg}$, respectively. ${ }^{15}$ Moreover, Gac peel extract using ethyl acetate showed the ABTS antioxidant capacity yield of $737 \mu \mathrm{M}$ trolox equivalent (TE) /100 g dry weight (DW) with total carotenoids of $271.1 \mathrm{mg} / 100 \mathrm{~g} \mathrm{DW} .^{19}$ The seed of the fruit has also been found to be rich in chymotrypsin inhibitor. ${ }^{20}$ The antioxidant activities of a chymotrypsin inhibitor from Gac seed have been established in rat hepatocyte culture exposed to tert-butyl hydroperoxide ( $t$-BHP)-induced oxidative stress. ${ }^{21}$

\section{Anticancer Activity of Gac Fruit}

Several studies investigated the ability of Gac fruit extract to inhibit and suppress the proliferation of several cancer cell lines via various mechanisms. A crude water extract obtained from the Gac fruit was assessed to determine its antitumor and Anti-angiogenic activities in vitro and in vivo, which resulted in the cell proliferation of two cancer cell lines (colon 26-20 and HepG2 cells) significantly inhibited when treated with the water extract. Indeed, the crude water extract was able to suppress the progression of cancer by reducing the wet tumour weight by $23.6 \%$ in a 'rat' cancer group. Moreover, histology and immunohistochemistry investigations appeared significant toward decreasing vascularisation for the Gac treated group. ${ }^{22}$ It was also reported that a water extract taken from Gac aril significantly reduced the cell viability of two cancer cell lines, notably MCF-7 breast cancer and melanoma with a rate of $60 \%$ and $71 \%$, respectively. ${ }^{11}$ Notwithstanding, Gac aril extract has shown an anticancer effect against the human MCF-7 breast cancer cell line by both apoptosis pathways (intrinsic and extrinsic). The mixture of hexane, acetone, and ethanol was successfully used to extract carotenoids from Gac aril that were then compared with lycopene and tamoxifen. Cell shrinkage and chromatin condensation have also been induced by aril extract using 4',6-diamidino-2-phenylindole (DAPI) fluorescent staining, while flow cytometry assay showed a higher percentage of MCF-7 cells in the early apoptosis stage. Moreover, aril extract was found to be capable of enhancing the activity of caspase- $6,-8$, and -9 , where the expression of the proapoptotic BAX gene dramatically increased when assessed by Real-time polymerase chain reaction (RT-PCR). ${ }^{10}$

Furthermore, the anticancer potentiality of $\mathrm{Gac}$ seed extract was also investigated in a study which showed that Gac seed extract appeared to exhibit potent inhibitory effects against human breast cancer ZR-75-30 cells. Moreover, the extract significantly repressed the expression secretion of two matrix metalloproteinases MMP-2 and MMP-9 when assessed based on western blot and gelatin zymography tests. ${ }^{23}$ The anticancer activity of Gac seed extract was further explored on human SGC7901 and MKN-28 gastric cancer cell lines, where the 3-(4,5-dimethylthiazol-2-yl)-2,5-diphenyltetrazolium bromide (MTT)

assay revealed that the survival of both cell lines had significantly decreased when compared with the control. Furthermore, Gac seed extracts were able to promote apoptosis by increasing the enzyme activities of caspase- 3 and -9 and via PARP and p53 signal pathways. ${ }^{24}$ Notably, the antiproliferative activity of Gac seed extract has been established again, and the ethanolic extract of Gac seed was found to be capable of suppressing the proliferation of A549 lung cancer cells by inducing apoptosis via the activation of p53 and inactivation of PI3K/Akt signalling. ${ }^{25}$ Recently, Gac seed extracts showed anticancer potential activity against two melanoma (MM418C1 and D24) cell lines. ${ }^{26}$

\section{DNA Protective Activity of Gac Fruit}

The DNA protective effect of Gac fruit against TK6 human lymphoblast cells, induced by $\mathrm{H}_{2} \mathrm{O}_{2}$ and ultraviolet UVC was investigated. In the previous study, it was found that TK6 exposure to $50 \mu \mathrm{M} \mathrm{H}_{2} \mathrm{O}_{2}$ for $5 \mathrm{~min}$, produced massive oxidative DNA damage, while TK6 exposure to UVC significantly enhanced DNA migration, when the TK6 cells were treated with Gac peel extract using ethanol $95 \%$ and $50 \%$, thus leading to a significant decrease in DNA damage. ${ }^{27}$

\section{Antimicrobial Activity of Gac Fruit}

Gac pulp (flesh) and seed pulp (aril) were examined concerning their potential activity against different strains of both Gram-positive and Gram-negative bacteria. The results of such work indicated that water and ethanolic extraction of Gac pulp displayed higher antibacterial effect on Gram-positive strains than Gram-negative strain bacteria. Accordingly, the highest antibacterial activity was observed in the ethanolic extract of Gac flesh against both strains, Micrococcus luteus 745 (20 mm) and M. luteus $884(18.5 \mathrm{~mm})$ inhibition zone. ${ }^{28}$ Another study assessed the antimicrobial activities from various parts of the Gac fruit (i.e. peel, pulp, and aril) against six pathogenic bacteria (Escherichia coli, Staphylococcus aureus, Bacillus cereus, Pseudomonas aeruginosa, Salmonella typhimurium, and Klebsiella pneumonia). Such results demonstrated that the data of this study confirmed that ethanolic extraction of various parts from Gac fruit had antimicrobial activity against all pathogenic strains, as mentioned previously. ${ }^{29}$

\section{Antiulcer Activity of Gac Fruit}

It has also been documented that 7 and 14 days of treatment with an ethanolic extract of Gac seed, significantly accelerates the healing of acetic acid via enhancing and upregulation of the angiogenesis, and increases the expression of mRNA as well as the vascular endothelial growth factor (VEGF), tested by real-time PCR and western blot. ${ }^{29}$

\section{Anti-inflammatory Activity of Gac Fruit}

Surprisingly, Gac seed is found to be a rich source of saponins, which are known for their health benefits. ${ }^{30}$ Two triterpenoid saponin compounds (Gypsogenin glycoside and Quillaic acid glycoside) were isolated and examined regarding their anti-inflammatory activity. For example, compound 2 (Quillaic acid glycoside) which is a saponin compound that isolated from Gac seed demonstrated anti-inflammatory effects in RAW 264.7 cells via inhibiting the lipopolysaccharide-induced expression of nitric oxide and IL- 6 via the NF- $\kappa B$ pathway. ${ }^{31}$

\section{Other Health Benefits of Gac Fruit}

Recently, two saponin compounds which were isolated from Gac seed showed a promising therapeutic effect against 
cisplatin-induced renal damage in LLC-PK1 kidney cells in vitro via blocking mitogen-activated protein kinases (MAPKs) signalling cascade. ${ }^{32}$ Likewise, the gastroprotective effect of Momordica semen extract has also been explored in vivo. The pre-treatment with Momordica saponin I as an ingredient isolated from the Momordica seed decreased gastric mucosa damage, thereby reducing the progressing acute and chronic gastrointestinal disorders (e.g., gastritis and gastric ulcer). ${ }^{33}$ The adverse reproductive parameters of male rats induced by valproic acid (VPA) was investigated. The $M$. cochinchinensis aril was mixed with distilled water, filtered, then dried and given orally to the rats in different concentrations. The protective effect of the extract against adverse male reproductive parameters and testicular damage induced by VPA was evident; the aril extract significantly protects the decrease of the weights of the epididymis and seminal vesicle. The aril extract also increased the sperm concentration and seminiferous diameter. Moreover, testicular histology tests confirmed dramatically declining testicular histopathologies as compared with the VPA group. ${ }^{34}$ Table 1 explained the biological activities of Gac fruit parts extracts.

\section{Further Discussion and Integration}

This study aims to scientifically summarise the literature studies that have characterised the bioactive compounds in Gac fruit and its portions. However, there is limited literature presently

\begin{tabular}{|c|c|c|c|}
\hline Gac part & Type of study & Health benefits & Mechanism of actions \\
\hline Fresh Gac aril & Clinical trial & Provitamin A activity & Improve $\beta$-carotene status which may lead to improve eye vision? \\
\hline Gac peel, pulp and aril & In vitro & DNA protective activity & Decrease DNA damage induced by $\mathrm{H}_{2} \mathrm{O}_{2}$ and UVC. ${ }^{27}$ \\
\hline Water extract of Gac aril & In vitro and In vivo & $\begin{array}{l}\text { Anti-tumor and Anti-angiogenic } \\
\text { activities }\end{array}$ & $\begin{array}{l}\text { Inhibition of the growth of colon adenocarcinoma cell, reduce } \\
\text { wet tumor, reduce the blood vessels density around the } \\
\text { carcinoma. }{ }^{22}\end{array}$ \\
\hline Gac aril & In vitro & Anticancer activity & $\begin{array}{l}\text { Suppression of the proliferation of breast cancer (MCF7) and } \\
\text { melanoma (MM418C1 and D24) cell lines.1 }\end{array}$ \\
\hline Gac pulp and aril & In vitro & Antimicrobial activity & Inhibition Gram-positive and Gram-negative bacteria growth. ${ }^{28}$ \\
\hline Peel, pulp and aril & In vitro & Antioxidant and antimicrobial & $\begin{array}{l}\text { Scavenge radical activity and ferric reducing power, inhibition } \\
\text { growth of different pathogenic bacteria such as (E. coli, S. } \\
\text { aureus, and B. cereus). }{ }^{16}\end{array}$ \\
\hline Gac aril & In vitro & Anticancer & $\begin{array}{l}\text { Induce cell apoptosis of MCF-7 via intrinsic and extrinsic } \\
\text { signalling pathways. }\end{array}$ \\
\hline Gac seed & In vitro & Anti-inflammatory activity & $\begin{array}{l}\text { Reduce the production of nitric oxide (NO), decrease mRNA } \\
\text { level of NO synthase (iNOS) and cyclooxygenase (COX)-2, } \\
\text { inhibit the translocation of p } 65 \text { and p50 of RAW } 264.7 . .^{35}\end{array}$ \\
\hline Gac aril & In vivo & $\begin{array}{l}\text { Male reproductive improve- } \\
\text { ment }\end{array}$ & $\begin{array}{l}\text { Protected against decrease weights of epididymis and seminal } \\
\text { vesicle, increased sperm concentration and seminiferous } \\
\text { tubular diameters. }\end{array}$ \\
\hline Gac seed & In vitro & Anti-inflammatory & $\begin{array}{l}\text { Inhibited lipopolysaccharide-induced expression of nitric oxide } \\
\text { and IL-6 via NF-kB pathway. }{ }^{31}\end{array}$ \\
\hline Gac seed & In vivo & $\begin{array}{l}\text { Anti-gastritis and wound heal- } \\
\text { ing activities }\end{array}$ & $\begin{array}{l}\text { Protective effect in a helicobacter pylori-insulted gastritis } \\
\text { model, wound healing effect on cutaneous injury and stim- } \\
\text { ulation of calcitonin gene-related peptide and somatostatin } \\
\text { receptors. }{ }^{33}\end{array}$ \\
\hline Gac seed & In vitro & Renoprotective activity & $\begin{array}{l}\text { Ameliorate of cisplatin-induced nephrotoxicity effect, blocking } \\
\text { of MAPKs signalling cascade. } .^{32}\end{array}$ \\
\hline Gac seed & In vivo & $\begin{array}{l}\text { Antiulcer and wound healing } \\
\text { activities }\end{array}$ & $\begin{array}{l}\text { Acceleration of gastric ulcer healing via upregulation of VEGF } \\
\text { expression in an acetic acid rat model.29 }\end{array}$ \\
\hline Gac seed & In vitro & Anticancer activity & $\begin{array}{l}\text { Inhibition cell survival of SGC7901 and MKN-28 gastric cancer } \\
\text { cells, seed treatment block the cell cycle at S phase downreg- } \\
\text { ulation of PARP and Bel-2 proteins, activation of the enzymatic } \\
\text { pathways caspase- } 3,-9 \text { and }-8 .{ }^{24}\end{array}$ \\
\hline Gac seed & In vitro & Anticancer activity & $\begin{array}{l}\text { Inhibition the A549 and } \mathrm{H} 1299 \text { lung cancer cell growth, induce } \\
\text { apoptosis via upregulation of p53, Bax and downregulation of } \\
\text { BCl-2 and PI3K/Akt signal pathways. }\end{array}$ \\
\hline Gac seed & In vitro & Anticancer activity & $\begin{array}{l}\text { Suppression the proliferation and inhibit the invasion and } \\
\text { migration of the breast cancer cell line (ZR-75-30), inhibition } \\
\text { the expression of MMP-2 and MMP-9..3 }\end{array}$ \\
\hline Gac seed & In vitro & Antioxidant activities & $\begin{array}{l}\text { Improve hepatocytes cell damage induced by } t-B H P \text {, decreased } \\
\text { lipid peroxidation and oxidized glutathione (GSSH) that in- } \\
\text { duced by } t \text {-BHP and increased glutathione (GSH) depletion. }{ }^{21}\end{array}$ \\
\hline Gac seed & In vitro & $\begin{array}{l}\text { Antioxidants and anticancer } \\
\text { activities }\end{array}$ & $\begin{array}{l}\text { Free radical scavenging via DPPH and ABTS tests and ferric } \\
\text { reducing power, suppression of the proliferation of human } \\
\text { melanoma cells MM418C1 and D24 lines. }{ }^{26}\end{array}$ \\
\hline
\end{tabular}


available regarding the biological activity of Gac fruit to fight against and prevent disease-causing cell damage such as cancer, diabetes and its complications, obesity, inflammation, atherosclerosis, cardiovascular disease, and microbial infections. Moreover, a limited number of published papers have reported the abundance of multiple phytochemicals (e.g., carotenoids, phenolic compounds, flavonoids, vitamin E, and essential fatty acid) in Gac fruit and its portions. The richness and abundance of the Gac fruit in various bioactive compounds also make it a 'super' fruit possessing several health benefits. It is worth mentioning that the superiority of this fruit will undoubtedly attract the best researchers in this field in undertaking challenging and possibly lucrative investigations in the future.

Furthermore, most of the studies related to Gac fruit have mainly emphasised the phytochemicals and/or bioactive compound contents especially carotenoid pigments. Due to the presence and high concentrations of carotenoids, this also gives the Gac fruit it's bright, shiny, deep orange-red colour. Indeed, $\beta$-Carotene, lycopene, and lutein were the primary carotenoids that were mostly quantified..$^{1,5-7,9,11}$ Most of the previous studies investigated the Gac fruit-rich extract, with little focus on the actual compounds. Therefore, the purification of $\beta$-Carotene, lycopene, and lutein and their application separately, could be more effective and conducive to various diseases. Fortunately, carotenoids in Gac fruit are mostly combined with oil and essential fatty acids. This characteristic enhances the priority and thereby promoting the advantages in the overall process of producing Gac fruit than other fruits and vegetables. Indeed, this is mainly because of the oil aiding in the absorption and digestion of carotenoids in the gastrointestinal tract in the digestive system. ${ }^{12,36}$

The phytonutrients in the parts of the Gac fruit (i.e. peel, pulp, and aril) and discussed earlier in this study, have been found to be rich in carotenoids. However, from among these portions, only the aril is processed while the other parts, like the peel and pulp, are usually discarded and considered as wastage, rather than valuable carotenoids or bi-products of the fruit. ${ }^{3,4}$ Surprisingly, the concentration of lutein is considerably high in Gac peel compared with the other parts. ${ }^{5}$ Lutein is one of the carotenoid pigments (xanthophylls) found to be uniquely concentrated in the retina of the eye. ${ }^{37}$ Interestingly, several studies have reported that low levels of lutein are associated with eye impairment and disorders such as diabetic retinopathy and age related-macular degradation. Prior studies have also revealed that diabetic retinopathy (DR) and age-related macular degeneration (AMD) are related to having a relatively lower level of lutein and other xanthophylls. ${ }^{38,39}$ Therefore, Gac peel-rich lutein pigment should be utilised and processed as a significant source of lutein supplementation rather than merely being wasted and discarded.

DR and AMD are the leading cause of blindness in developing and developed countries as mentioned earlier and are characterised by chronic exposure of hyperglycaemia by the retina ${ }^{40-42}$ However, the present treatment of the disease has many drawbacks such as retinal haemorrhage, retinal detachments, in addition to the treatment costs which place a considerable burden on the patients and their families. ${ }^{43-45}$ The role of carotenoid pigments in the protection and avoidance of eye disease has been well acknowledged in the literature. ${ }^{46-48}$ Therefore, based upon the information presented and discussed in this review, and to the best of the author's knowledge, there have been no studies investigating the use of Gac fruit-rich carotenoid extracts for the treatment of eye disorders such as $\mathrm{DR}$ and AMD.

Many pathophysiological pathways are involved in the development and progression of DR and AMD diseases, ${ }^{49}$ and many of which have faced speculation toward the disruption of the balance of the ocular angiogenesis process in favour of pro-angiogenic signals. ${ }^{50}$ Despite the recent progress in understanding the pathogenesis of $\mathrm{DR}$ and $\mathrm{AMD}$, including the role of growth factors, the diseases are still neither preventable nor curable. However, recent studies have indicated that regulating angiogenic markers may be an opportunistic target in the treatment of DR and AMD. ${ }^{51}$ Currently, attempts have been made to utilise phytotherapy such as medical herbalism, which relies on an empirical appreciation of medicinal herbs and its nutraceuticals due to the degree of safeness, efficacy and pharmacological action in the prevention and treatment of chronic diseases. ${ }^{52-55}$ For the later reasons, numerous efforts have been employed for screening and development of Anti-angiogenic products from natural sources. Notwithstanding, previous attempts have also been used on several phytochemicals and their derived metabolites from various medicinal plants, by testing their action and response as Anti-angiogenic agents. ${ }^{48,56}$ The outcome of such studies was promising but far from perfect and acceptable, due to the low level of extracted carotenoids, particularly lutein in the extraction yield. As mentioned previously, Gac fruit is abundantly rich in carotenoids and contains high quantities of lutein as compared with other medicinal plants. Indeed, this advantage could enable novel, if not innovative approaches to be adapted to extract a prominent level of carotenoids from the fruit, and to examine its pharmacological effect and biological mechanisms of action. Likewise, the determination of the pharmacological function using combined and individual molecules can also lead to exploring the mechanisms of action. Discovering the mechanistic pathway by which the mechanism derives the molecules, and reverse or normalise the angiogenic process in diabetic patient's eyes would be incredibly valuable. However, to date, there have been no large-scale studies to investigate the effect of the Gac fruit's rich extract against angiogenesis markers related to eye disease among all levels including in vitro, in vivo, and clinical studies. Therefore, Gac fruit and its multi-content of phytochemicals and especially carotenoids could be an ideal agent for a myriad of diseases, but further research studies would still be required to investigate the efficacy, the nature and role of Gac fruit and its bioactive compounds by the combined and synergistic use. Figure 2 shows the potential future work that can be conducted using Gac fruit and its parts extracts.

herefore, considering all the information discussed, discovering new sources that would be able to regress, slowdown, or delay the progression of DR and AMD would be highly advantageous and recommended. Finally, Gac fruit-rich carotenoids may be a potential agent to control or to balance the angiogenesis process, which may open and expose new insights and knowledge for the cure and treatment of angiogenesis-related eye diseases.

\section{Conclusion}

Gac (M. cochinchinensis Spreng.) fruit, is a conventional fruit found in Vietnam and other Southeast Asian countries, which contains relatively high levels of carotenoids, especially lycopene and $\beta$-Carotene. The Gac fruit is a distinctive and promising phytonutrient which has been used for generations for 


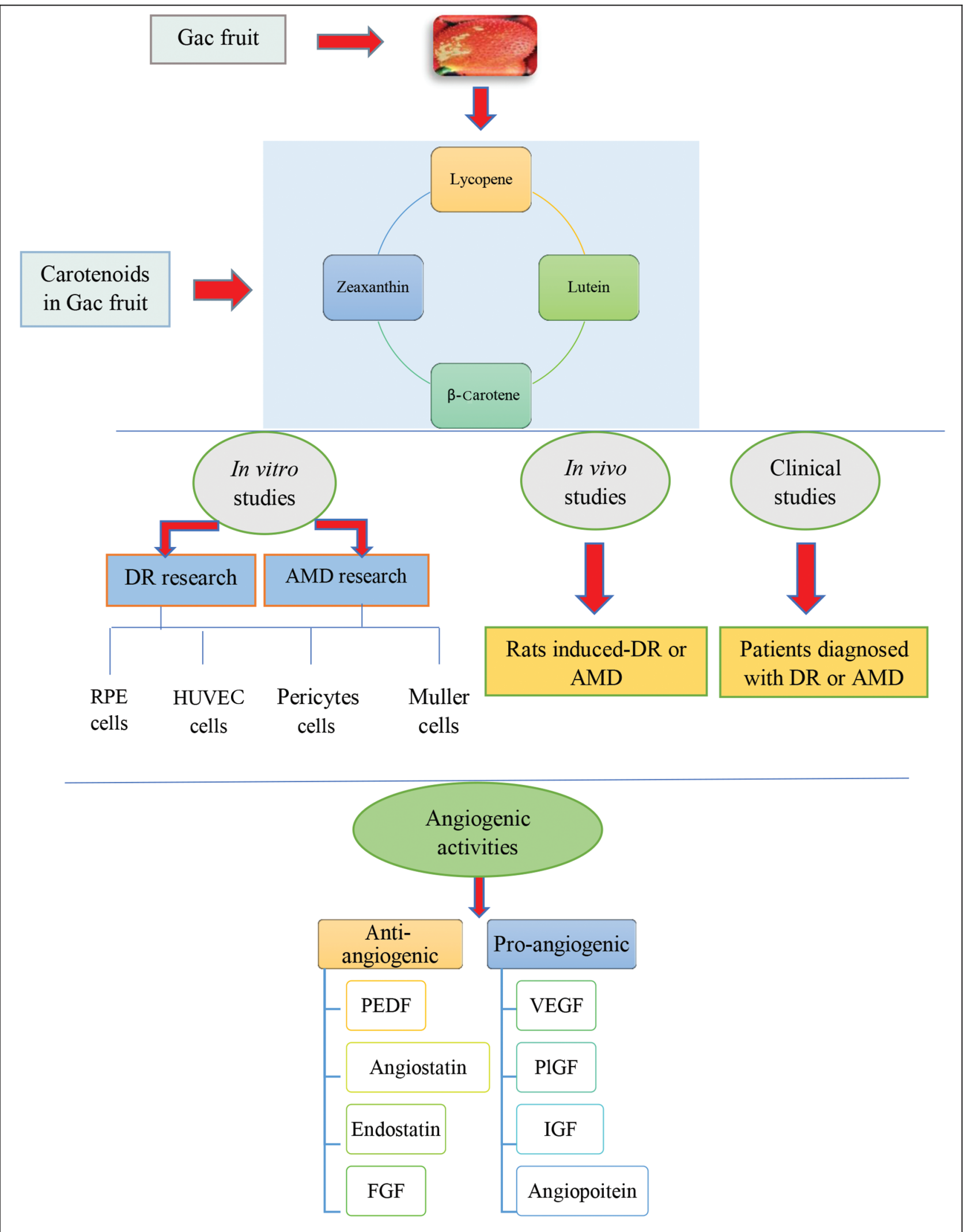

Fig. 2 Potential future research on Gac fruit-rich carotenoids fruit. RPE, retinal pigmented epithelial cells; HUVEC, human umbilical vein endothelial cells; PEDF, pigment epithelium-derived factor; FGF, fibroblast growth factor; VEGF, vascular endothelial growth factor; PIGF, placenta like growth factor; IGF, insulin-like growth factor. 
both nutritional and medicinal purposes. Additionally, used in the body, $\beta$-Carotene is converted to vitamin $\mathrm{A}$, thereby enhancing the immune system, helping to prevent eye-associated diseases. Indeed, studies undertaken in recent years have exploited this conviction by revealing the high levels of antioxidants contained in the fruit. Therefore, it is not surprising to observe the current research in nutritional sciences and health now being directed with utmost enthusiasm and motivation toward this unique fruit at both the cellular and molecular levels.

\section{Acknowledgement}

We would like to acknowledge the staff in the library of the Faculty of Medicine and Health Sciences at Universiti Putra
Malaysia for their valuable assistance in the management and collection of literature and research papers.

\section{Author Contributions}

AA perfumed the work and manuscript formatting; FA conceived, supervised and edited the review; AI and NE supervised, and contributed to the structure of the manuscript and review. All authors read and approved the final manuscript.

\section{Conflict of Interest}

The authors have no conflict of interest related to this manuscript.

\section{References}

1. Ishida BK, Turner C, Chapman MH, McKeon TA. Fatty acid and carotenoid composition of gac (Momordica cochinchinensis Spreng) fruit. J Agric Food Chem. 2004;52:274-279.

2. Vuong LT. Gac: a fruit from heaven. Vietnam J. 2003.

3. Chuyen H, Nguyen MH, Roach PD, Golding JB, Parks SE. Gac fruit (Momordica cochinchinensis Spreng.): a rich source of bioactive compounds and its potential health benefits. Int J Food Sci Technol. 2015;50:567-577.

4. Kha TC, Nguyen MH, Roach PD, Parks SE, Stathopoulos C. Gac fruit: nutrient and phytochemical composition, and options for processing. Food Rev Int. 2013:29:92-106

5. Kubola J, Siriamornpun S. Phytochemicals and antioxidant activity of different fruit fractions (peel, pulp, aril and seed) of Thai gac (Momordica cochinchinensis Spreng). Food Chem. 2011;127:1138-1145.

6. Aoki H, Kieu NT, Kuze N, Tomisaka K, Van Chuyen N. Carotenoid pigments in GAC fruit (Momordica cochinchinensis SPRENG). Biosci Biotechnol Biochem. 2002;66:2479-2482.

7. Vuong le, Dueker SR, Murphy SP. Plasma $\beta$-Carotene and retinol concentrations of children increase after a 30-d supplementation with the fruit Momordica cochinchinensis (gac). Am J Clin Nutr. 2002;75:872-879.

8. Vuong LT, Franke AA, Custer LJ, Murphy SP. Momordica cochinchinensis Spreng.(gac) fruit carotenoids reevaluated. J Food Compos Anal. 2006; 19:664-668.

9. Nhung DT, Bung PN, Ha NT, Phong TK. Changes in lycopene and beta carotene contents in aril and oil of gac fruit during storage. Food Chem. 2010;121:326-331

10. Petchsak P. Sripanidkulchai B. Momordica cochinchinensis aril extract induced apoptosis in human MCF-7 breast cancer cells. Asian Pac J Cancer Prev. 2015;16:5507-5513.

11. Wimalasiri D, Piva T, Huynh T. Diversity in Nutrition and Bioactivity of Momordica cochinchinensis. Int J Adv Sci Eng Inf Technol. 2016;6:378-380.

12. Müller-Maatsch J, Sprenger J, Hempel J, Kreiser F, Carle R, Schweiggert RM Carotenoids from gac fruit aril (Momordica cochinchinensis [Lour.] Spreng.) are more bioaccessible than those from carrot root and tomato fruit. Food Res Int. 2017;99:928-935.

13. Vuong LT. Underutilized $\beta$-Carotene-rich crops of Vietnam. Food Nutr Bull. 2000;21:173-181.

14. Nhi TT, Tuan DQ. Enzyme assisted extraction of GAC oil (Momordica cochinchinensis Spreng) from dried aril. J Food Nutr Sci. 2016:4:1-6.

15. Bharathi LK, Singh HS, Shivashankar S, Ganeshamurthy AN, Sureshkumar P. Assay of nutritional composition and antioxidant activity of three dioecious Momordica species of South East Asia. Proc Natl Acad Sci India Sec B. 2014;84:31-36

16. Tinrat S, Akkarachaneeyakorn S, Singhapol C. Evaluation of antioxidant and antimicrobial activities of Momordica cochinchinensis Spreng (Gac fruit) ethanolic extract. Int J Pharm Sci Res. 2014;5(8):3163-3169.

17. Xiao CW, Hu SH, Rajput ZI. Adjuvant effect of an extract from Cochinchina momordica seeds on the immune responses to ovalbumin in mice. Front Agric China. 2007;1:90-95

18. Rahmatullah M, Biswas A, Haq WM, Seraj S, Jahan R. An ethnomedicinal survey of cucurbitaceae family plants used in the folk medicinal practices of Bangladesh 1. Chron Young Sci. 2012; 3: 212-222.

19. Chuyen HV, Roach PD, Golding JB, Parks SE, Nguyen MH. Optimisation of extraction conditions for recovering carotenoids and antioxidant capacity from Gac peel using response surface methodology. Int J Food Sci Technol. 2017;52:972-980.

20. Tsoi AY, Wong RC, Ng TB, Fong WP. First report on a potato I family chymotrypsin inhibitor from the seeds of a Cucurbitaceous plant, Momordica cochinchinensis. Biol Chem. 2004;385:185-189.

21. Tsoi AY, Ng TB, Fong WP. Antioxidative effect of a chymotrypsin inhibitor from Momordica cochinchinensis (Cucurbitaceae) seeds in a primary rat hepatocyte culture. J Pept Sci. 2005:11:665-668.

22. Tien PG, Kayama F, Konishi F, Tamemoto H, Kasono K, Hung NT, et al. Inhibition of tumor growth and angiogenesis by water extract of Gac fruit (Momordica cochinchinensis Spreng). Int J Oncol. 2005;26:881-889.

23. Zheng L, Zhang YM, Zhan YZ, Liu CX. Momordica cochinchinensis seed extracts suppress migration and invasion of human breast cancer ZR-75-30 cells via down-regulating MMP-2 and MMP-9. Asian Pac J Cancer Prev. 2014:15:1105-1110.

24. Liu HR, Meng LY, Lin ZY, Shen Y, Yu YQ, Zhu YZ. Cochinchina momordica seed extract induces apoptosis and cell cycle arrest in human gastric cancer cells via PARP and p53 signal pathways. Nutr Cancer. 2012;64:1070-1077.

25. Shen Y, Meng L, Sun H, Zhu Y, Liu H. Cochinchina momordica seed suppresses proliferation and metastasis in human lung cancer cells by regulating multiple molecular targets. Am J Chin Med. 2015:43:149-166.

26. Le A, Huynh T, Parks S, Nguyen M, Roach P. Bioactive composition, antioxidant activity, and anticancer potential of freeze-dried extracts from defatted Gac (Momordica cochinchinensis Spreng) seeds. Medicines (Basel). 2018;5. pii: E104.

27. Klungsupya P, Saenkhum J, Muangman T, Rerk-Am U, Laovitthayanggoon S, Leelamanit W. Non-cytotoxic property and DNA protective activity against $\mathrm{H}_{2} \mathrm{O}_{2}$ and UVC of Thai GAC fruit extracts in human TK6 cells. J Appl Pharm Sci. 2012;2:4-8

28. Innun A. I-SEEC 2012. Proceeding-Science and Engineering. 2013;1-6.

29. Kang JM, Kim N, Kim B, Kim JH, Lee BY, Park JH, et al. Enhancement of gastric ulcer healing and angiogenesis by cochinchina Momordica seed extract in rats. J Korean Med Sci. 2010;25:875-881.

30. Lin ZY, Liu X, Yang F, Yu YQ. Structural characterization and identification of five triterpenoid saponins isolated from Momordica cochinchinensis extracts by liquid chromatography/tandem mass spectrometry. Int J Mass Spectrom. 2012:328-329:43-66

31. Jung K, Chin YW, Yoon Kd, Chae HS, Kim CY, Yoo H, et al. Anti-inflammatory properties of a triterpenoidal glycoside from Momordica cochinchinensis in LPS-stimulated macrophages. Immunopharmacol Immunotoxicol. 2013:35:8-14.

32. Jung K, Lee D, Yu JS, Namgung $H$, Kang KS, Kim KH. Protective effect and mechanism of action of saponins isolated from the seeds of gac (Momordica cochinchinensis Spreng.) against cisplatin-induced damage in LLC-PK1 kidney cells. Bioorg Med Chem Lett. 2016;26:1466-1470.

33. Jung K, Chin YW, Chung YH, Park YH, Yoo H, Min DS, et al. Anti-gastritis and wound healing effects of Momordicae Semen extract and its active component. Immunopharmacol Immunotoxicol. 2013:35:126-132.

34. Sukhorum W, Sampannang A, Sripanidkulchai B, lamsaard S. Momordica cochinchinensis (L.) Spreng. Aril Extract prevents adverse reproductive parameters of male rats induced with valproic acid. Int J Morphol. 2016;34:870-877. 
35. Yu JS, Kim JH, Lee S, Jung K, Kim KH, Cho JY. Src/Syk-targeted anti-inflammatory actions of triterpenoidal saponins from Gac (Momordica cochinchinensis) seeds. Am J Chin Med. 2017;45:459-473.

36. Failla ML, Chitchumronchokchai C, Ferruzzi MG, Goltz SR, Campbell WW. Unsaturated fatty acids promote bioaccessibility and basolateral secretion of carotenoids and $a$-tocopherol by Caco-2 cells. Food Funct. 2014;5:1101-1112.

37. Handelman GJ, Snodderly DM, Adler AJ, Russett MD, Dratz EA. Measurement of carotenoids in human and monkey retinas. Meth Enzymol. 1992:213:220-230.

38. Hu BJ, Hu YN, Lin S, Ma WJ, Li XR. Application of lutein and zeaxanthin in nonproliferative diabetic retinopathy. Int J Ophthalmol. 2011:4:303-306.

39. Brazionis L, Rowley K, Itsiopoulos C, O'Dea K. Plasma carotenoids and diabetic retinopathy. Br J Nutr. 2009:101:270-277.

40. Boscia F. Current approaches to the management of diabetic retinopathy and diabetic macular oedema. Drugs. 2010;70:2171-2200.

41. Barot M, Gokulgandhi MR, Patel S, Mitra AK. Microvascular complications and diabetic retinopathy: recent advances and future implications. Future Med Chem. 2013;5:301-314.

42. Curcio CA. Soft drusen in age-related macular degeneration: biology and targeting via the oil spill strategies. Invest Ophthalmol Vis Sci. 2018;59:AMD160-AMD181.

43. Simó $R$, Hernández $C$. Advances in the medical treatment of diabetic retinopathy. Diabetes care. 2009;32:1556-1562.

44. Selvaraj K, Gowthamarajan K, Karri VV, Barauah UK, Ravisankar V, Jojo GM. Current treatment strategies and nanocarrier based approaches for the treatment and management of diabetic retinopathy. J Drug Target. 2017:25:386-405.

45. Austeng D, Morken TS, Bolme S, Follestad T, Halsteinli V. Nurse-administered intravitreal injections of anti-VEGF: study protocol for noninferiority randomized controlled trial of safety, cost and patient satisfaction. BMC Ophthalmol. 2016;16:169.

46. Krinsky NI, Johnson EJ. Carotenoid actions and their relation to health and disease. Mol Aspects Med. 2005:26:459-516.
47. Gorusupudi A, Nelson K, Bernstein PS. The age-related eye disease 2 study: micronutrients in the treatment of macular degeneration. Adv Nutr. 2017:8:40-53.

48. Wu J, Cho E, Willett WC, Sastry SM, Schaumberg DA. Intakes of lutein, zeaxanthin, and other carotenoids and age-related macular degeneration during 2 decades of prospective follow-up. JAMA Ophthalmol. 2015:133:1415-1424.

49. Xu HZ, Song Z, Fu S, Zhu M, Le YZ. RPE barrier breakdown in diabetic retinopathy: seeing is believing. J Ocul Biol Dis Infor. 2011;4:83-92.

50. Babapoor-Farrokhran S, Jee K, Puchner B, Hassan SJ, Xin X, Rodrigues M, et al. Angiopoietin-like 4 is a potent angiogenic factor and a novel therapeutic target for patients with proliferative diabetic retinopathy. Proc Natl Acad Sci USA. 2015;112:E3030-E3039.

51. Tolentino MS, Tolentino AJ, Tolentino MJ. Current and investigational drugs for the treatment of diabetic retinopathy. Expert Opin Investig Drugs. 2016;25:1011-1022

52. AL-Zuaidy MH, Mumtaz MW, Hamid AA, Ismail A, Mohamed S, Razis AFA. Biochemical characterization and $1 \mathrm{H}$ NMR based metabolomics revealed Melicope lunu-ankenda leaf extract a potent anti-diabetic agent in rats. BMC Complement Altern Med. 2017;17:359.

53. Abu Bakar Sajak A, Mediani A, Maulidiani, Mohd Dom NS, Machap C, Hamid M, et al. Effect of Ipomoea aquatica ethanolic extract in streptozotocin (STZ) induced diabetic rats via $1 \mathrm{H}$ NMR-based metabolomics approach. Phytomedicine. 2017;36:201-209

54. Khazaei MR, Makalani F, Ghanbari E, Fayzemahdavi M, Khazaei M. An overview of effective herbal and antioxidant compounds on diabetes. J Contemp Med Sci. 2018:4:126-133.

55. Albosof F, Hoseini SA, Siahpoush A, Malayeri AR, Haghighizadeh MH Anti-diabetic effects of $S$. aegyptiaca extract on streptozotocin-nicotinamide induced type 2 diabetes rats. J Contemp Med Sci. 2018;4:22-25.

56. Xing Q, Zhang G, Kang L, Wu J, Chen H, Liu G, et al. The suppression of kallistatin on high-glucose-induced proliferation of retinal endothelial cells in diabetic retinopathy. Ophthalmic Res. 2017;57:141-149. 